\title{
EFFECT OF GYPSUM, SUGAR FACTORY LIME AND MOLAS ON SOME SOIL PROPRIETIES AND PRODUCTIVITY OF SUGAR BEET(Beta vulgaris I.) GROWN ON SALINE-SODIC SOILS OF NILE NORTH DELTA
}

Amer, M. M.

Soils, Water and Environment Research Institute, Agricultural Research

Center, Egypt

Corresponding author: Megahed Amer (dr_megahed120@yahoo.com)

\section{ABSTRACT}

Two field trials were carried out at the Experimental Farm, Sakha Agricultural Research Station, North Delta during the two successive winter growing seasons of $2012 / 2013$ and $2013 / 2014$. The research aimed to study the of effect application of gypsum, mixture (byproduct of sugar factory lime treated by commercial $\mathrm{H}_{2} \mathrm{SO}_{4}$ ) and molas and their interaction on some salt affected soils properties, yield of sugar beet (Beta vulgaris L.), field water use efficiency (FWUE) and their economic efficiency. The experiments were designed as split-split plot with three replicates. The main plots were occupied by gypsum, $\mathrm{G}\left(0,5,7.5,10 \mathrm{Mg} \mathrm{Fed}^{-1}\right)$, sub plots were devoted to sugar lime mixture, SLM $\left(0,4,6 \mathrm{MgFed}^{-1}\right)$ and the sub-sub plots were molas, M $(0$, 30, 60 L Fed. $^{-1}$ ).

The results showed that the amendments addition clearly improved some chemical properties of the studied soil. The common parameters of saline sodic soil i.e., EC, sodium adsorption ratio (SAR), exchangeable sodium percentage (ESP), bulk density and hydraulic conductivity(H.C) were clearly improved by application of gypsum,. The results showed that combined treatments were more efficient than single one. Increase the rate of used gypsum led to a decrease in salinity as well as sodicity. The mean values of EC, SAR and ESP were decreased by $-43.6 \%,-56.79 \%$ and $-37.56 \%$, respectively due to application of gypsum up to $10 \mathrm{Mg} \mathrm{fed}^{-1}$, as compared to that without application. Application of sugar lime mixture (SLM) and molas had insignificant effect on soil ECe, SAR and ESP after the harvesting of sugar beet in both growing seasons. Data show that soil ECe, SAR and ESP recorded lowest value due to the interaction between $G^{*} S L M^{*} M$ Percentage of Na-removed from the soils at the end of the experiment was about $51 \%$ due to the interaction between gypsum, sugar lime mixture and molas up to $10,6 \mathrm{Mg} \mathrm{fed.}^{-1}$ and 60LFed. ${ }^{-1}$, respectively. On the other hand, the highest values of soil infiltration rate and hydraulic conductivity were found with the interaction between gypsum, SLM and molas as compared to the control.

Roots, the top yields of sugar beet, sucrose (\%) and extractable sugar yield were high significantly increased with application of gypsum up to $10 \mathrm{Mg} \mathrm{fed}^{-1}$ and/or with the interaction between all amendments during both growing seasons. Also, root $\mathrm{N}, \mathrm{Na}$ and $\mathrm{K} \%$ after harvesting, were high significantly increased due to the interaction between all amendments during both seasons. Sugar recovery and recoverable sugar yield were high significantly increased due to the interaction between all amendments. The highest net income values from water unit $(1.93,1.42$ and $1.28 \mathrm{LE} / \mathrm{m}^{3}$ water) were obtained with the application of $10 \mathrm{Mg}$ gypsum fed $^{-1}, 6$ Mg sugar lime mixture fed ${ }^{-1}$ and $30 \mathrm{~L}_{\text {molas fed. }}{ }^{-1}$, respectively. The highest total and net income were recorded with the interaction between $10 \mathrm{Mg}$ gypsum fed $^{-1}, 6 \mathrm{Mg}$ lime Fed ${ }^{-1}$ and $60 \mathrm{~L}_{\text {Molas Fed. }}^{-1}$. The amendment can be arranged, due to its effect on root of sugar beet, total income, net income, Net efficiency from water unit and economic Eff. in the order of: $G^{*} S L M^{*} M>G^{*} S L M>G^{*} M>G>S L M^{*} M>S L M>M$

Finally, the most effective treatment was the interaction between $G^{*} S L M^{\star} M$. 
Keywords: Salt-affected soils, soil conditioners, soil properties, sugar beet, sugar recovery, economical evaluation

\section{INTRODUCTION}

Currently, at least $20 \%$ of the world's irrigated land is salt-affected. Among those affected by salt, about $60 \%$ are sodic, (Qadir et al., 2006). Salt affected soils represent $9.1 \%$ from the total area and $30 \%$ from the total cultivated area in Egypt, (FAO 2005). Therefore, improving salt affected soils in Egypt could be considered as an important issue in the agricultural security program (Abdel-Fattah 2012). Furthermore, these soils could be classified into three groups (saline, sodic and saline-sodic soils) depending upon the nature and amount of soluble salts affecting the physicochemical characteristic, colour, process of formation, plant response and the management practices (Richards 1954). Several studies have been carried out concerning the effectiveness of various amendments in improving the physical and chemical properties of saline sodic and sodic soils (Hanay et al., 2004; Amezketa et al., 2005 and Amer and El-Ramady 2015). Salt-affected soils could be remediated using three amendment groups: (1) chemical agents, including calcium compounds (gypsum, calcium chloride or calcite), (2) sulfur compounds (elemental-S, sulphuric acid or pyrite) and (3) organic matter or amendments (farmyard manure, compost, green manure and municipal solid waste). These previous materials are successful approaches that have been implemented worldwide, being simple, low cost, and effective (Tejada et al., 2006 and Cha-um and Kirdmanee 2011). Avnimelech et al. (1992) found that the application of gypsum to a saline sodic soil led to the dissolution of $\mathrm{CaCO}_{3}$, and increase soluble calcium; causing an effective displacement and leaching of sodium from the soil. Abdurrahman et al. (2004) reported that the application of gypsum alone to saline alkaline soil has successfully reduced its EC and ESP values. EC decreased from 12.35 to $1.98 \mathrm{dS} \mathrm{m}^{-1}$, and ESP from 14.75 to $6.69 \%$. llyas et al.(1997) indicated that gypsum application increased the soluble $\mathrm{Na}^{+}$in the top $20 \mathrm{~cm}$ soil. However, one year after the treatment, under crop rotation and addition of gypsum; SAR, EC, $\mathrm{pH}$ and $\mathrm{Cl}^{-}$in top $20 \mathrm{~cm}$ of soil were significantly decreased.

The relative effect of gypsum and sulphuric acid has received the most attention because they are widely used as reclamation amendments. Most recently, crops or crops residues and synthetic polymers have been included in efficiency studies (Hanay et al..2 2004). Gypsum is mainly blamed for its slow reaction but much popular due to its low cost and availability. One of the major shortcomings in gypsum use is its application at uniform rates, which lower its efficiency because of the special variability under the salt affected soil conditions. The efficiency of gypsum can be increased if it applied at variable rates according to the requirements of the soil but again it needs extra economical analysis. One of the major reasons of low productivity of crops grown under saline sodic conditions is the salt toxicity. Being easily available and cheap source of calcium, gypsum is commonly used in Egypt. Because of the low solubility of gypsum, its effect in the 
amelioration process continues for few months until the whole of gypsum reacts with the exchangeable sodium of the soil.

It is well known that sugar factory lime $(S L)$ is a byproduct obtained from the beet sugar industry at the stage of purification of raw juice by milk of lime and $\mathrm{CO}_{2}$ gases and the main part of this byproduct consists of $\mathrm{CaCO}_{3}$ containing up to $25.7 \%$ of $\mathrm{CaO}$, (Abd El-Hamid et al.,2011).And contain organic acids (acetic acid and carbonic acid), $5 \mathrm{Mg}$ from sugar factory lime $\equiv$ $1 \mathrm{Mg}$ gypsum reported by (EL Morsey,2014). SL usually is a fine particle size, and may include byproduct organic matter needed to the soil (Ag Gold Standard , 2008). It is also an aggregated powder of light brown colour and its chemical composition is variable depending among other factors. These lime wastes could be used to reclaim the saline-sodic soils. Dickson et al. (1990) found that sugar lime interest mainly due to the increase in organic matter concentration (about 2\%) and, to a lesser extent, by increases in calcium carbonate (more than $30 \%$ ) and $\mathrm{P}$ (four times more). The soil pH was also found to increase slightly (1.4\%), while the electrical conductivity almost did not change. The properties associated with these pedological qualities therefore had a positive effect by improving nutrient availability. Although the $\mathrm{Na}^{+}$content in sugar lime was high, the relative amount of it with respect to the $\mathrm{Ca}^{2+}$ and $\mathrm{Mg}^{2+}$ content will not cause a problem with regard to changes in the SAR. In many factories in Egypt, there are tremendous amount of industrial byproducts from sugar factories, which are increased annually without utilization causing environmental pollution. These byproduct lime stones contain organic matter and have relatively high CEC values. Thus, a great challenge exists to find a beneficial use for the large quantity of lime wastes generated each year (Ippolito et al. ${ }_{2}$ 2013). Sharma et al (1996) found that sulphuric acid lowers the soil $\mathrm{pH}$, reacts with soluble carbonates and replaces the exchangeable sodium with calcium. Sulphuric acid reacts with sugar lime to form gypsum $(\mathrm{CaSO} 4.2 \mathrm{H} 2 \mathrm{O})$ and increase soluble carbonates . Mohamedin et al.(2012) stated that the effectiveness of the soil amendments on soil and crop improvement could be arranged in the descending order: gypsum +FYM > sugar lime +FYM > gypsum > sugar lime > FYM > control. The treatments consisted of gypsum (G) at $50 \%$ gypsum requirement (GR=10.4 Mgfed. ${ }^{-1}$ for the $0-15 \mathrm{~cm}^{-1}$ soil depth), sugar lime (SL) at $50 \% \mathrm{GR}$, farmyard manure (FYM) $20 \mathrm{~m}^{3}$ fed. $^{-1}$

Consequently, the utilization of sugar factory lime from the dump is a very important for the environment. Therefore, the main objective of this investigation was to study the ameliorative effect of gypsum, sugar factory lime treated with sulphuric acid as well as molas and their combinations on properties of salt affected soil, sugar beet yield, and water use efficiency.

\section{MATERIALS AND METHODS}

\section{Experimental design}

Two field experiments were conducted at Sakha Agricultural Research Station Farm, North Delta, during two successive winter growing seasons (2012/2013 and 2013/2014) to study the effect of some soil 
amendments on the productivity of sugar beet in salt affected soils. The site is located at $31^{\circ} 07 \mathrm{~N}$ latitude and $30^{\circ} 57 \mathrm{E}$ longitude with an elevation of about 6 meters above sea level. The experiments were designed as split-split plot with three replicates. The main plots were occupied by gypsum, $\mathrm{CaSO}_{4 \cdot 2} \mathrm{H}_{2} \mathrm{O}$ (98\% purity) at the rate of $0,5,7.5$ and $10 \mathrm{Mg}$ fed $^{-1}$ which represent $0,27,40$ and $53 \%$ from gypsum requirements, respectively. The gypsum was thoroughly mixed with the top $15 \mathrm{~cm}$ soil layer. Sub plots were devoted to mixture from sugar lime which treated by the commercial $\mathrm{H}_{2} \mathrm{SO}_{4}$ $\left(5 \mathrm{LMg}^{-1}\right.$ sugar lime) at the rate of 0,4 , and $6 \mathrm{Mg}_{\text {fed. }}{ }^{-1}$. The sub-sub plots were for molas $\left(0,30\right.$ and $\left.60 \mathrm{~L} \mathrm{fed}^{-1}\right)$.

\section{Soil sampling and analysis:}

Disturbed and undisturbed soil samples were taken in the initial and after harvesting of sugar beet. The disturbed soil samples were prepared for physical and chemical analysis according to the standard methods. Exchangeable cations $\mathrm{Ca}, \mathrm{Mg}, \mathrm{K}$ and $\mathrm{Na}$, soluble cations and anions as well as soil $\mathrm{pH}$ and $\mathrm{EC}$ were determined in soil paste extract, organic matter and total calcium carbonate were determined according to Page et al. (1982).Sodium adsorption ratio (SAR) estimated by using the following equation, where ionic concentration of the saturation extracts is expressed in meq $\mathrm{L}^{-1}$ according to Abdel - Fattah (2012)

$$
\text { SAR }=\frac{\mathrm{Na}}{\sqrt{\left(\mathrm{Ca}^{2+}+\mathrm{Mg}^{2+}\right) / 2}}
$$

Gypsum requirement ( $\mathrm{Mg} \mathrm{fed}^{-1}$ ) were determined according to Oster and Frenkel (1980).

At the same time, undisturbed soil samples were taken to determine of bulk density according to Blake and Hartge (1986), hydraulic conductivity was measurements by auger hole method according to Van Beers (1958) and infiltration rate was determined using double cylinder infiltrometer as described by Garcia (1978) as shown in Tables(1\&2). The experimental area was ploughed three times, settled, ridged and divided into plots $(3 \times 3.5 \mathrm{~m})$ during soil preparation. Sugar beet seeds were obtained from Sugar Research Institute, Agriculture Research Centre, Giza, Egypt.

\section{Characterization of used amendments}

The chemical composition of byproduct of sugar factory lime treated by commercial $\mathrm{H}_{2} \mathrm{SO}_{4}$ was as follows: $\mathrm{N}, \mathrm{P}, \mathrm{K}, \mathrm{Mn}, \mathrm{Cu}$, as well as $\mathrm{CaCO}_{3}$ were $0.94,0.28,0.06,3.42,0.21$ and $23.1 \%$. PH, (8.01) and $\mathrm{EC}\left(14.3 \mathrm{dSm}^{-1}\right)$

Whereas, the chemical composition of sugar beet molas (in \%) was as follow : $\mathrm{NO}_{3}, \mathrm{PO}_{4}, \mathrm{~K}, \mathrm{Ca}, \mathrm{Mg}, \mathrm{Na}, \mathrm{Cl}, \mathrm{SO}_{4}$ were $(0.2-0.6),(0.05-0.35)$, $(2-6),(1-1.5),(0.01-2),(0.4-2.5),(0.5-2.5)$, and $(0.45-1.5)$, respectively. Also, molas includes $48 \%$ sucrose, $12-20 \%$ water , $1 \%$ starch and polysaccharides, $3 \%$ dextrin and cellulose, $8-12 \%$ total $\mathrm{N}$ content, $7-12 \%$ crude protein, $2-3 \%$ glutamic acid, and some vitamins (in $\mathrm{mg} \mathrm{kg}^{-1}$ ) including pyridoxine or B6 (5), thiamine or B1 (1.3), riboflavin or B2 (0.4). Some non-nitrogenous organic acids (in \%) also are included in molas such as lactic $(1.0-1.7)$, citric, glycolic, malic $(0.5-1.0)$, oxalic, succinic $(0-0.2)$, acetic $(0-0.2)$, propinic $(0-0.2)$, and putyric $(0-0.2)$. 
Table 1: Chemical soil characterization of the experimental site before cultivation

\begin{tabular}{|c|c|c|c|c|c|c|c|}
\hline Depth(cm) & Soil pH & $\begin{array}{c}E C \\
\left(\mathrm{dS}^{-1}\right)\end{array}$ & SAR & ESP (\%) & $\begin{array}{c}\text { CEC } \\
\left(\mathrm{cmole} \mathrm{kg}^{-1}\right)\end{array}$ & $\underset{\left(\mathrm{g} \mathrm{kg}^{-1}\right)}{\mathrm{OM}}$ & $\underset{\%}{\mathrm{CaCO}_{3}}$ \\
\hline $0-20$ & 8.26 & 15.40 & 24.5 & 25.84 & 40.0 & 12.1 & 2.81 \\
\hline $20-40$ & 8.25 & 15.55 & 26.3 & 27.28 & 39.0 & 12.0 & 2.72 \\
\hline $40-60$ & 8.27 & 15.69 & 26.6 & 27.49 & 37.0 & 9.1 & 1.89 \\
\hline Mean & 8.26 & 15.55 & 25.77 & 26.87 & 38.67 & 11.07 & 2.47 \\
\hline
\end{tabular}

Soil $\mathrm{pH}$ was determined in soil water suspension (1:2.5), whereas soil EC was determined in saturated soil paste extract, SAR, ESP and CEC represents sodium adsorption ratio, exchangeable sodium percent and cation exchange capacity, respectively.

Table 2: Physical soil characterization of the experimental site before cultivation

\begin{tabular}{|c|c|c|c|c|c|c|c|c|c|c|}
\hline \multirow[b]{2}{*}{$\begin{array}{l}\text { Soil } \\
\text { depth }(\mathrm{cm})\end{array}$} & \multirow[b]{2}{*}{$\begin{array}{c}\mathrm{K}, \\
\mathrm{cm} \mathrm{h}^{-1}\end{array}$} & \multirow[b]{2}{*}{$\begin{array}{l}\text { IR, } \\
\mathrm{cm} \mathrm{h}^{-1}\end{array}$} & \multicolumn{4}{|c|}{ Soil moisture characteristics } & \multicolumn{4}{|c|}{ Particle size distribution (\%) } \\
\hline & & & $\begin{array}{c}\text { Field } \\
\text { Capacity } \\
(\%)\end{array}$ & $\begin{array}{l}\text { WP } \\
\text { (\%) }\end{array}$ & $\begin{array}{l}\text { AW } \\
\text { (\%) }\end{array}$ & $\begin{array}{c}\text { BD } \\
\left(\mathrm{kg} \mathrm{m}^{-3}\right)\end{array}$ & $\mathbf{S}$ & Silt & Clay & $\begin{array}{r}\text { Sc } \\
\text { text }\end{array}$ \\
\hline & \multirow{3}{*}{2.31} & \multirow{3}{*}{0.62} & 41.1 & 1 & ( & & 6.7 & 31.2 & 52.1 & \\
\hline $20-40$ & & & 40.1 & 22.0 & 18.5 & 1.40 & 15.92 & 30.98 & 53.1 & Clayey \\
\hline $40-60$ & & & 38.6 & 21.1 & 18.1 & 1.45 & 15.62 & 30.78 & 53.6 & Claye \\
\hline
\end{tabular}

K, IR, WP, AW, and BD represents hydraulic conductivity, infiltration rate, welting point, available water and bulk density, respectively

\section{Water use efficiency and sugar quality:}

Water use efficiency (WUE): was calculated according to Howell et al. (1990) using the following equation: WUE $\left(\mathrm{kg} \mathrm{m}^{-3}\right)=(\mathrm{Ey} / \mathrm{ET})$

Where: Ey is the economical yield $(\mathrm{kg} / \mathrm{fed} /$ season) and ET is the total applied of irrigation water $\left(\mathrm{m}^{3} \mathrm{fed}^{-1} \mathrm{season}^{-1}\right)$.

- amount of irrigation water applied $\left(\mathrm{m}^{3} \mathrm{fed} \mathrm{f}^{-1}\right)$ was measured by using cutthroat flume $(30 \times 90 \mathrm{~cm})$ according to Early,(1975).

\section{Plant sampling and analysis:}

At harvest, plants were taken from each plot $\left(10.5 \mathrm{~m}^{2}\right)$ to determine root and shoot yield (Mg fed. $\left.{ }^{-1}\right) .10 \mathrm{~kg}$ of roots were taken randomly from each plot and sent to the Beet Laboratory at EL-Hamool Sugar Factory to determine root quality. Sugar yield $\left(\mathrm{Mg} \mathrm{fed}^{-1}\right)$ was calculated by multiplying root yield by sucrose percent. Alpha amino nitrogen ( $\alpha$-amino $N$ ), sodium $(\mathrm{Na})$ and potassium $(\mathrm{K})$ concentrations were estimated according to the procedure of sugar company by auto analyzer described by Cooke and Scott (1993). Total soluble salts (TSS) and sucrose percent estimated in fresh samples of sugar beet root by using Saccharometer according to AOAC (1995). Some parameters were calculated as follows:

$$
\begin{array}{ll}
\text { Sugar loss }(\%) & =0.29+0.343(\mathrm{~K}+\mathrm{Na})+0.094 \alpha \text {-amino } \mathrm{N} \\
\text { Gross sugar yield }\left(\mathrm{Mg} \mathrm{fed}^{-1}\right) & =\text { root yield }\left(\mathrm{Mg} \mathrm{fed}^{-1}\right) \times \text { sucrose }(\%) \\
\text { Sugar loss yield } & =\text { root yield }\left(\mathrm{Mg} \mathrm{fed}^{-1}\right) \times \text { sugar loss }(\%) \\
\text { Sugar recovery }(\%) & =\text { sucrose }(\%)-\text { sugar loss }(\%), \text { Cooke and Scott }(1993)
\end{array}
$$




\section{Recoverable sugar yield $\left(\mathrm{Mg} \mathrm{fed}^{-1}\right)$ according to Mohamed (2002):} $=$ root yield $\left(\mathrm{Mg} \mathrm{fed}^{-1}\right) \times$ sugar recovery $(\%)$

\section{Statistical analyses:}

The obtained resulted were subjected to analyses of variance according to the procedure outlined by Gomez and Gomez (1984), and significant differences were weighted by LSD test at 0.05 level of probability.

\section{RESULTS AND DISCUSSIONS}

\section{Soil chemical properties:}

It is well known that soil salinity (ECe), sodium adsorption ratio (SAR), exchangeable sodium percent (ESP) as well as soil reaction $(\mathrm{pH})$ are most chemical parameters concerning the salt-affected soils. Therefore, these parameters totally depend on different soil amendments under these soils, a suitable solution should be found to overcome the salinity and alkalinity problems under these conditions. Therefore, these chemical parameters will be focused on in this study.

\subsection{Soil salinity (EC) :}

Gypsum had a high significant effect on decreasing salinity of the soil after the harvesting of plants during the two growing seasons as shown in Table (3). Data show that the mean values of ECe were decreased by about $29.54,36.57$ and $43.60 \%$ with the application of $5,7.5$ and $10 \mathrm{Mg}$ gypsum fed. ${ }^{-1}$, respectively. Concerning the effect of sugar lime mixture and molas application to the soil cultivated by sugar beet, the data show insignificant change in the EC values after harvesting in the two growing seasons .

Gypsum amendment was relatively more effective in reducing the EC values than SLM and molas application. This may be due to the effective solubility of gypsum, which increased considerably because the exchanger phase serves as a sink for the dissolved Ca-ions. These results are in the same line with those obtained by Dickson et al. (1990) and Abdurrahman et al. (2004).

\subsection{Soil alkalinity (SAR and ESP) :}

Data presented in Tables ( 3 and 4 ) pointed out that SAR values were decreased with increasing of gypsum application rates up to $10 \mathrm{Mg}$ fed. ${ }^{-1}$ comparing with the control during both growing seasons. The data show that the mean values of SAR were decreased by about 29.68, 38.74 and $56.79 \%$ with application of $5,7.5$ and $10 \mathrm{Mg}$ gypsum fed. ${ }^{-1}$, respectively. The same trend was observed also with ESP, where its_values were decreased by

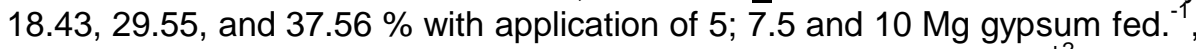
respectively. This may be due to the dominance of soluble $\mathrm{Ca}^{+2}$ on the exchange complex. These results are in agreement with llyas et al.(1997), Abdurrahman et al. (2004) and Mansour et.al. (2011). Data show that ESP was increased as affected by SLM application compared with untreated ones. However, such increase was insignificant. On the other hand, the application of molas slightly affected the values of soil ECe, SAR and ESP after harvesting of sugar beet.

In general, data pointed out that the application of sugar lime mixture (SLM) had little positive effect on decreasing the values of soil ECe and SAR 
after the harvesting of sugar beet in both growing seasons. where, such decrease was insignificant. The application of $6 \mathrm{Mg} \mathrm{SLM} \mathrm{fed.}^{-1}$ recorded the highest mean decrease values of ECe and SAR (-0.9 and-3.93) respectively. Data concluded that ECe, ESP and SAR were recorded lowest value due to the interaction between gypsum, SLM and molas. Also, the removal sodium efficiency (RSE) or percentage of Na-removed from the soils at end of the experiment was significantly reduced after the application of the amendments where the highest value $(51 \%)$ was found due to the interaction between gypsum, SLM and molas up to $10,6 \mathrm{Mg} \mathrm{fed.}^{-1}$ and 60LFed. ${ }^{-1} 1$.

Table(3): Some chemical characteristics of the soil after harvesting of sugar beet as affected by amendments application during two growing seasons

\begin{tabular}{|c|c|c|c|c|c|c|c|}
\hline \multicolumn{2}{|c|}{ Mean effects } & \multicolumn{3}{|c|}{$1^{\text {st }}$ season } & \multicolumn{3}{|c|}{$2^{\text {nd }}$ season } \\
\hline Treatments & Rates & EC & SAR & ESP & EC & SAR & ESP \\
\hline \multirow{4}{*}{$\begin{array}{l}\text { Gypsum } \\
\left(\text { Mg fed }^{-1}\right)\end{array}$} & 0 & $15.46 \mathrm{a}$ & $26.39 \mathrm{a}$ & $21.93 \mathrm{a}$ & $16.57 \mathrm{a}$ & $28.68 \mathrm{a}$ & $21.63 \mathrm{a}$ \\
\hline & 5 & $11.75 \mathrm{~b}$ & $20.24 b$ & $17.86 \mathrm{~b}$ & $10.81 \mathrm{~b}$ & $18.48 \mathrm{~b}$ & $17.67 \mathrm{~b}$ \\
\hline & 7.5 & $10.74 \mathrm{c}$ & $17.82 \mathrm{c}$ & $15.59 \mathrm{c}$ & $9.57 \mathrm{c}$ & $15.91 \mathrm{c}$ & $15.10 \mathrm{c}$ \\
\hline & 10 & $9.66 \mathrm{~d}$ & $12.52 \mathrm{~d}$ & $13.66 \mathrm{~d}$ & $8.40 \mathrm{~d}$ & $11.27 \mathrm{~d}$ & $13.54 \mathrm{~d}$ \\
\hline \multirow{3}{*}{$\begin{array}{l}\text { sugar lime } \\
\text { mixture (Mg } \\
\text { fed }^{-1} \text { ) }\end{array}$} & 0 & $11.95 \mathrm{a}$ & $19.37 \mathrm{a}$ & $17.00 \mathrm{a}$ & $11.31 \mathrm{a}$ & $19.06 \mathrm{a}$ & $16.64 \mathrm{a}$ \\
\hline & 4 & $11.89 \mathrm{a}$ & $19.17 \mathrm{a}$ & $17.12 \mathrm{a}$ & $11.30 \mathrm{a}$ & $18.61 \mathrm{a}$ & $17.20 \mathrm{a}$ \\
\hline & 6 & $11.76 \mathrm{a}$ & $18.99 \mathrm{a}$ & $17.65 \mathrm{a}$ & $11.29 \mathrm{a}$ & $17.92 \mathrm{a}$ & $17.12 \mathrm{a}$ \\
\hline \multirow{3}{*}{$\begin{array}{l}\text { Molas } \\
\left(\text { L fed }^{-1}\right)\end{array}$} & 0 & $11.87 \mathrm{a}$ & $19.16 \mathrm{a}$ & $17.37 \mathrm{a}$ & $11.30 \mathrm{a}$ & $18.85 \mathrm{a}$ & $17.01 \mathrm{a}$ \\
\hline & 30 & $11.87 \mathrm{a}$ & $19.25 \mathrm{a}$ & $17.14 \mathrm{a}$ & $11.30 \mathrm{a}$ & $18.32 \mathrm{a}$ & $17.09 \mathrm{a}$ \\
\hline & 60 & $11.88 \mathrm{a}$ & $19.14 \mathrm{a}$ & $17.27 \mathrm{a}$ & $11.30 \mathrm{a}$ & $18.44 \mathrm{a}$ & $16.86 \mathrm{a}$ \\
\hline \multirow{4}{*}{ Interaction } & $\mathrm{G} \times \mathrm{SLM}$ & ns & * & * & $\mathrm{ns}$ & * & * \\
\hline & $G \times M$ & ns & * & * & ns & * & * \\
\hline & SLM $\times M$ & ns & ns & ns & ns & ns & ns \\
\hline & $G \times S L M \times M$ & * & * & 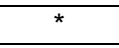 & * & 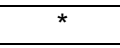 & 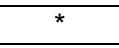 \\
\hline
\end{tabular}

Table (4): Relative change ( $\pm \%$ ) of some chemical characteristics of the soil after har vesting of sugar beet as affected by amendments (mean of two growing seasons)

\begin{tabular}{|c|c|c|c|c|}
\hline Treatments & Rates & $\begin{array}{c}\text { Relative change } \\
\text { in EC (\%) }\end{array}$ & $\begin{array}{c}\text { Relative change } \\
\text { in SAR (\%) }\end{array}$ & $\begin{array}{c}\text { Relative change } \\
\text { in ESP (\%) }\end{array}$ \\
\hline \multicolumn{2}{|c|}{ initial soil before cultivation } & 15.55 & 25.77 & 26.87 \\
\hline \multirow{4}{*}{$\begin{array}{l}\text { Gypsum } \\
\text { (Mg fed-1) }\end{array}$} & 0 & 16.01 & 27.53 & 21.78 \\
\hline & 5 & -29.54 & -29.68 & -18.43 \\
\hline & 7.5 & -36.57 & -38.74 & -29.55 \\
\hline & 10 & -43.60 & -56.79 & -37.56 \\
\hline \multirow{3}{*}{$\begin{array}{l}\text { sugar lime } \\
\text { mixture } \\
\left(\text { Mg fed }^{-1}\right)\end{array}$} & 0 & 11.63 & 19.21 & 16.81 \\
\hline & 4 & -0.30 & -1.67 & +2.08 \\
\hline & 6 & -0.90 & -3.93 & +3.42 \\
\hline \multirow{3}{*}{$\begin{array}{l}\text { Molas } \\
(\text { L fed-1) }\end{array}$} & 0 & 11.59 & 19.3 & 16.06 \\
\hline & 30 & 0.0 & -1.16 & -0.44 \\
\hline & 60 & 0.0 & -1.13 & -0.73 \\
\hline
\end{tabular}

\section{Soil physical properties:}

It is well known that soil bulk density (BD), porosity, infiltration rate (IR) and hydraulic conductivity (K) are the most physical parameters 
concerning the water movement in soils. Due to the effect of high $\mathrm{Na}$ and soluble salts content under saline-sodic soils, the water movement will find difficulties under these conditions. Therefore, these physical parameters will be focused on in this study.

\subsection{Soil bulk density and its porosity:}

Data in Table (5) show that the soil bulk density was decreased as affected by all treatment compared with untreated ones. However, such decrease was insignificant

Data show that the porosity were improved with different soil amendments. The application of gypsum high significantly increased the soil porosity and consequently while the soil bulk density was decreased. In both growing seasons, the highest mean values of soil porosity (51.8 and 52.9, respectively) and soil bulk density (1.3 and $1.31 \mathrm{Mg} \mathrm{m}^{-3}$, respectively) were recorded with application of $10 \mathrm{Mg}$ gypsum fed ${ }^{-1}$. This means the highest application rate of gypsum (10 Mg fed. ${ }^{-1}$ ) achieved the highest decrease in soil bulk density and the highest increase in soil porosity. With respect to the effect of sugar lime mixture on soil porosity, it is pointed out that was significantly increased with increasing of SLM application rate up to $6 \mathrm{Mg}$ fed.

${ }^{1}$ comparing with control during both growing seasons. While soil porosity was insignificant effect with molas application. These results may be attributed to the role of soil amendments in increasing exchangeable calcium which enhance the aggregation process and consequently increase apparent soil bulk volume, decrease soil bulk density and increase the efficiency of leaching processes. The obtained results are similar to those reported (Habib et al., 2009 and Abd El-Hamid et al. 2011).

\subsection{Infiltration rate (IR) and hydraulic conductivity (K):}

Regarding the soil infiltration rate and hydraulic conductivity, it is found that the application of gypsum high significantly increased both parameters due to the high significantly increasing in soil porosity as shown in Table (5). In the two growing seasons, the highest mean values of soil IR (1.01 and $1.12 \mathrm{~cm} \mathrm{~h}^{-1}$, respectively) and soil $\mathrm{K}\left(8.7\right.$ and $9.8 \mathrm{~cm} \mathrm{~h}^{-1}$, respectively) were recorded with application of $10 \mathrm{Mg} \mathrm{gypsum} \mathrm{fed}^{-1}$.

Table(6) show that the mean values of soil IR were high significantly increased by $30.7,39.3$ and $42.0 \%$ with application of $5,7.5$ and $10 \mathrm{Mg}$ gypsum fed ${ }^{-1}$, respectively. The same trend was observed also with soil $\mathrm{K}$, where its values were high significantly increased by 69.1, 157.6, and 197.9 $\%$ with application of 5,7.5 and $10 \mathrm{Mg}$ gypsum fed. ${ }^{-1}$, respectively.

It is clear that the highest value of $\mathrm{K}$ was found with the combined application of gypsum, sugar lime mixture and molas. This result may be attributed to the decreased of ECe and bulk density values in the treated soil. Also, the amendments enhanced the soil aggregates which increase both of total porosity and drainable pores. Whereas the field area of study is a good drainage efficiency. These results are similar to that reported by ElSamanoudi et al., (1991), Ali (1993) and Abdurrahman et al. (2004) .

From the abovementioned results, it could be concluded that gypsum the cheapest soil amendment's still the most favorable and suitable one comparing with sugar lime. On the other hand, sugar lime is the waste product of sugar factories could be used taken firstly, the environmental 
awareness in consideration and secondly for its contents of calcium and organic acids. These results are similar to that reported by Mohamedin et al.,(2012).

Table (5): Some physical characteristics of the soil after harvesting of sugar beet as affected by amendments application during two growing seasons

\begin{tabular}{|c|c|c|c|c|c|c|c|c|c|}
\hline \multirow[b]{2}{*}{ Treatments } & \multirow[b]{2}{*}{ Rates } & \multicolumn{4}{|c|}{$1^{\text {st }}$ season } & \multicolumn{4}{|c|}{$2^{\text {nd }}$ season } \\
\hline & & $\begin{array}{c}\mathrm{BD} \\
\left(\mathrm{Mg} \mathrm{m}^{-3}\right)\end{array}$ & $\begin{array}{c}\text { Porosity } \\
(\%)\end{array}$ & $\begin{array}{c}\text { IR, } \\
\mathrm{cm} \mathrm{h}^{-1}\end{array}$ & \begin{tabular}{|c|}
$\mathrm{K}$ \\
$\mathrm{cm} \mathrm{h}^{-1}$
\end{tabular} & $\begin{array}{c}\mathrm{BD}, \\
\mathrm{Mg} \mathrm{m}^{-3}\end{array}$ & $\begin{array}{c}\text { porosity } \\
(\%)\end{array}$ & $\begin{array}{c}\text { IR, } \\
\mathrm{cm} \mathrm{h}^{-1}\end{array}$ & $\begin{array}{c}\mathrm{K}, \\
\mathrm{cm} \mathrm{h}^{-1}\end{array}$ \\
\hline \multirow{4}{*}{$\begin{array}{l}\text { Gypsum } \\
\left(\text { Mg fed }^{-1}\right)\end{array}$} & 0 & $1.41 \mathrm{a}$ & $47.0 \mathrm{~d}$ & $0.65 c$ & $2.41 \mathrm{~d}$ & $1.37 \mathrm{a}$ & $48.9 d$ & $0.85 c$ & $3.8 d$ \\
\hline & 5 & $1.34 a$ & $47.6 c$ & $0.95 b$ & $4.90 c$ & $1.35 a$ & $49.5 c$ & $1.01 \mathrm{~b}$ & $5.6 c$ \\
\hline & 7.5 & $1.32 a$ & $48.7 b$ & $1.00 \mathrm{a}$ & $7.50 \mathrm{~b}$ & $1.36 \mathrm{a}$ & $51.2 b$ & $1.09 a$ & $8.5 b$ \\
\hline & 10 & $1.30 a$ & $51.8 \mathrm{a}$ & $1.01 \mathrm{a}$ & $8.70 a$ & $1.31 \mathrm{a}$ & $52.9 a$ & $1.12 \mathrm{a}$ & $9.8 a$ \\
\hline \multirow{3}{*}{$\begin{array}{l}\text { sugar lime } \\
\text { mixture } \\
\left(\text { Mg fed }^{-1}\right)\end{array}$} & 0 & $1.40 \mathrm{a}$ & $47.0 \mathrm{~b}$ & $0.60 \mathrm{~b}$ & $2.41 \mathrm{c}$ & $1.42 \mathrm{a}$ & $48.2 c$ & $0.75 c$ & $3.7 c$ \\
\hline & 4 & $1.38 a$ & $47.2 b$ & $0.68 a$ & $3.15 b$ & $1.45 a$ & $48.5 b$ & $0.80 \mathrm{~b}$ & $4.1 b$ \\
\hline & 6 & $1.37 a$ & $47.5 a$ & $0.69 a$ & $5.61 \mathrm{a}$ & $1.42 \mathrm{a}$ & $49.1 \mathrm{a}$ & $0.84 a$ & $5.9 a$ \\
\hline \multirow{3}{*}{$\begin{array}{l}\text { Molas } \\
\left(\text { L fed }^{-1}\right)\end{array}$} & 0 & $1.40 \mathrm{a}$ & $47.0 \mathrm{a}$ & $0.61 b$ & $2.41 \mathrm{c}$ & $1.40 \mathrm{a}$ & $48.1 \mathrm{a}$ & $0.71 b$ & $3.8 c$ \\
\hline & 30 & $1.38 a$ & $47.3 a$ & $0.65 a$ & $4.45 b$ & $1.42 \mathrm{a}$ & $48.2 a$ & $0.75 b$ & $5.4 b$ \\
\hline & 60 & $1.35 a$ & $47.5 a$ & $0.66 a$ & $6.71 \mathrm{a}$ & $1.42 \mathrm{a}$ & $48.3 a$ & $0.81 a$ & $7.5 a$ \\
\hline \multirow{4}{*}{ Interaction } & $G \times S L M$ & * & ns & * & * & $\mathrm{ns}$ & ns & * & * \\
\hline & $G \times M$ & ns & * & * & * & $\mathrm{ns}$ & * & * & * \\
\hline & SLM $\times M$ & ns & ns & * & * & ns & $\mathrm{ns}$ & * & * \\
\hline & $\mathrm{G} \times \mathrm{SLM} \times \mathrm{M}$ & * & * & * & ** & * & * & * & k* \\
\hline
\end{tabular}

$B D$, IR, and $K$ is represented soil bulk density, soil porosity, infiltration rate and hydraulic conductivity, respectively

Table (6): Relative change ( \pm \%) of some physical characteristics of the soil after harvesting of sugar beet as affected by amendments (mean of two growing seasons)

\begin{tabular}{|c|c|c|c|c|c|}
\hline \multicolumn{2}{|l|}{ Treatments } & \multirow{2}{*}{$\begin{array}{c}\begin{array}{c}\text { BD } \\
\left(\mathrm{Mg} \mathrm{m}^{-3}\right)\end{array} \\
1.39\end{array}$} & \multirow{2}{*}{$\begin{array}{c}\text { Porosity } \\
\text { (\%) }\end{array}$} & \multirow{2}{*}{$\begin{array}{c}\begin{array}{c}\text { IR, } \\
\mathbf{c m ~ h}^{-1}\end{array} \\
0.75\end{array}$} & \multirow{2}{*}{$\begin{array}{c}\begin{array}{c}\mathbf{K}, \\
\mathbf{c m ~ h}^{-1}\end{array} \\
3.11\end{array}$} \\
\hline \multirow{4}{*}{$\begin{array}{l}\text { Gypsum } \\
\left(\text { Mg fed }^{-1}\right)\end{array}$} & 0 & & & & \\
\hline & 5 & -3.2 & +1.3 & +30.7 & +69.1 \\
\hline & 7.5 & -3.6 & +4.2 & +39.3 & +157.6 \\
\hline & 10 & -6.1 & +9.2 & +42.0 & +197.9 \\
\hline \multirow{3}{*}{$\begin{array}{l}\text { sugar lime mixture } \\
\left(\mathrm{Mg} \mathrm{fed}^{-1}\right)\end{array}$} & 0 & 1.41 & 47.60 & 0.68 & 3.06 \\
\hline & 4 & -0.4 & +0.5 & +9.6 & +18.7 \\
\hline & 6 & -1.1 & +1.5 & +13.3 & +88.4 \\
\hline \multirow{3}{*}{$\begin{array}{l}\text { Molas } \\
\left(\text { L fed }^{-1}\right)\end{array}$} & 0 & 1.40 & 47.55 & 0.66 & 3.11 \\
\hline & 30 & 0.0 & +0.4 & +6.1 & +58.6 \\
\hline & 60 & -1.1 & +0.7 & +11.4 & +128.8 \\
\hline
\end{tabular}

\subsection{Field water use efficiency (WUE):}

It is well known that under saline-sodic soils, the water is the crucial factor regarding the crop production. Therefore, it is very important to evaluate the agricultural production in the point of view of the importance of water. So, sugar or root yields of sugar beet should be converted to the values of the yield produced by one $\mathrm{m}^{3}$ water which called water use efficiency (WUE). Therefore, WUE values for sugar and root yield of sugar 
beet as affected by different treatments were calculated under these salinesodic soils (Table, 7 ).

The WUE for both of roots and sugar yields were high significantly increased with the increasing of gypsum application rates up to $10 \mathrm{Mg} \mathrm{fed}^{-1}$. For the two growing seasons, the highest WUE values were 7.41 and $7.42 \mathrm{~kg} \mathrm{~m}^{-3}$, respectively for roots yield and 1.04 and $1.41 \mathrm{~kg} \mathrm{~m}^{-3}$, respectively for sugar yield were recorded with $10 \mathrm{Mg}$ gypsum $\mathrm{Fed}^{-1}$. Sugar lime mixture(SLM) and molas followed the same trend of gypsum, whereas the highest WUE values in both growing seasons for roots or sugar yield were recorded with the highest application rates of both amendments. Also, it could be concluded that water use efficiency for root and sugar were high significantly increased due to the interaction between gypsum, SLM and molas.

Table (7): Field water use efficiency (WUE) for sugar beet as affected by different treatments

\begin{tabular}{|c|c|c|c|c|c|}
\hline \multirow{2}{*}{ Treatments } & \multirow{2}{*}{ Rate } & \multicolumn{2}{|c|}{ WUE (kg roots $\mathrm{m}^{-3}$ ) } & \multicolumn{2}{|c|}{ WUE(kq sugar $\mathrm{m}^{-3}$ ) } \\
\hline & & $1^{\text {st }}$ season & $2^{\text {nd }}$ season & $1^{\text {st }}$ season & $2^{\text {nd }}$ season \\
\hline \multirow{4}{*}{$\begin{array}{l}\text { Gypsum (G) } \\
\mathrm{Mg} \mathrm{F}^{-1}\end{array}$} & 0 & $3.73 \mathrm{~d}$ & $3.76 \mathrm{~d}$ & $0.62 \mathrm{~d}$ & $0.62 \mathrm{~d}$ \\
\hline & 5 & $5.31 \mathrm{c}$ & $5.33 \mathrm{c}$ & $0.88 \mathrm{c}$ & $0.89 \mathrm{c}$ \\
\hline & 7.5 & $6.52 \mathrm{~b}$ & $6.54 \mathrm{~b}$ & $1.11 \mathrm{~b}$ & $1.12 \mathrm{~b}$ \\
\hline & 10 & $7.41 \mathrm{a}$ & $7.42 \mathrm{a}$ & $1.04 \mathrm{a}$ & $1.41 \mathrm{a}$ \\
\hline \multirow{3}{*}{$\begin{array}{l}\text { sugar lime } \\
\text { mixture } \\
\left(\mathrm{Mg} \mathrm{fed}^{-1}\right)\end{array}$} & 0 & $5.25 \mathrm{c}$ & $5.8 \mathrm{c}$ & $0.9 \mathrm{c}$ & $0.90 \mathrm{c}$ \\
\hline & 4 & $5.82 \mathrm{~b}$ & $5.84 \mathrm{~b}$ & $1.02 \mathrm{~b}$ & $1.03 \mathrm{~b}$ \\
\hline & 6 & $6.15 \mathrm{a}$ & $6.17 \mathrm{a}$ & $1.09 \mathrm{a}$ & $1.10 \mathrm{a}$ \\
\hline \multirow{3}{*}{$\begin{array}{l}\text { Molas (M) } \\
\mathrm{LF}^{-1}\end{array}$} & 0 & $5.52 \mathrm{c}$ & $5.51 \mathrm{c}$ & $0.95 \mathrm{c}$ & $0.95 \mathrm{c}$ \\
\hline & 30 & $5.79 \mathrm{~b}$ & $5.82 \mathrm{~b}$ & $1.02 \mathrm{~b}$ & $1.03 \mathrm{~b}$ \\
\hline & 60 & $5.92 \mathrm{a}$ & $5.95 \mathrm{a}$ & $1.05 \mathrm{a}$ & $1.05 \mathrm{a}$ \\
\hline \multirow{4}{*}{ Interaction } & $\mathrm{G} \times \mathrm{SLM}$ & ** & ** & ** & ** \\
\hline & $G \times M$ & ** & ** & ** & ** \\
\hline & SLM $\times M$ & ** & ** & ** & ** \\
\hline & $G \times S L M \times M$ & ** & ** & ** & ** \\
\hline
\end{tabular}

\section{Sugar beet yield and its quality:}

To evaluate the effects of gypsum, sugar lime mixture(SLM) and molas on sugar beet production under saline-sodic soils, different rates of them were applied. These previous amendments may be having a role in enhancing growing plants to overcome the problems resulting from soil salinity and its alkalinity. The yield of sugar beet crop and its quality are listed in Table (8). With respect to the effect of gypsum on root and shoot yields of sugar beet, it is pointed out that root and shoot yields of sugar beet, and sucrose percent were high significantly increased with increasing of gypsum application rate up to $10 \mathrm{Mg}$ fed..$^{-1}$ comparing with control during both growing seasons. In the two growing seasons the highest values of root yield (21.42, $21.54 \mathrm{Mg}$ fed. ${ }^{-1}$, respectively), shoot yield $\left(5.1,5.31 \mathrm{Mg}\right.$ fed. $^{-1}$, respectively) and sucrose percent $(18.96,18.97 \%$, respectively) were obtained with $10 \mathrm{Mg}$ gypsum fed. ${ }^{-1}$. The same trend was observed also with SLM and molas, where the application of $6 \mathrm{Mg} \mathrm{SLM}$ fed..$^{-1}$ or $60 \mathrm{~L}$ molas fed. ${ }^{-1}$ achieved the highest values of these parameters. These results are in the same line with those obtained by Dickson et al. (1990) and Mohamedin et al.,(2012). 
On the other side, it could be concluded that sugar beet root and shoot yields as well as sucrose percent were high significantly increased due to the interaction between gypsum, SLM and molas.

Table (8): Root, shoot and sugar yields as affected by different treatments

\begin{tabular}{|c|c|c|c|c|c|c|c|}
\hline \multirow[b]{2}{*}{ Treatments } & \multirow[b]{2}{*}{ Rates } & \multicolumn{2}{|c|}{$\operatorname{Root}\left(\mathrm{Mg} \mathrm{fed}^{-1}\right)$} & \multicolumn{2}{|c|}{ Shoot $\left(\mathrm{Mg} \mathrm{fed}^{-1}\right)$} & \multicolumn{2}{|c|}{ Sucrose (\%) } \\
\hline & & $\begin{array}{c}1^{\text {st }} \\
\text { season }\end{array}$ & $\begin{array}{c}2^{\text {nd }} \\
\text { season }\end{array}$ & $\begin{array}{c}1^{\text {st }} \\
\text { season }\end{array}$ & $\begin{array}{c}2^{\text {nd }} \\
\text { season }\end{array}$ & $\begin{array}{c}1^{\text {st }} \\
\text { season }\end{array}$ & $\begin{array}{c}2^{\text {nd }} \\
\text { season }\end{array}$ \\
\hline \multirow{4}{*}{$\mid \begin{array}{l}\text { Gypsum }(G) \\
\text { Mg Fed. }^{-1}\end{array}$} & 0 & $10.80 \mathrm{~d}$ & $10.90 \mathrm{~d}$ & $2.72 \mathrm{~d}$ & $2.73 \mathrm{~d}$ & $16.73 \mathrm{c}$ & $16.67 d$ \\
\hline & 5 & $15.37 \mathrm{c}$ & $15.47 \mathrm{c}$ & $3.46 c$ & $3.53 \mathrm{c}$ & $16.66 \mathrm{~d}$ & $16.74 \mathrm{c}$ \\
\hline & 7.5 & $18.87 \mathrm{~b}$ & $18.97 \mathrm{~b}$ & $4.17 \mathrm{~b}$ & $4.28 \mathrm{~b}$ & $17.11 \mathrm{~b}$ & $17.12 \mathrm{~b}$ \\
\hline & 10 & $21.42 \mathrm{a}$ & $21.54 \mathrm{a}$ & $5.10 \mathrm{a}$ & $5.31 \mathrm{a}$ & $18.96 \mathrm{a}$ & $18.97 \mathrm{a}$ \\
\hline \multirow{3}{*}{$\begin{array}{l}\text { SLM } \\
\text { Mg Fed. }^{-1}\end{array}$} & 0 & $15.21 \mathrm{c}$ & $15.31 \mathrm{c}$ & $3.51 \mathrm{c}$ & $3.58 \mathrm{c}$ & $17.10 \mathrm{c}$ & $17.06 \mathrm{c}$ \\
\hline & 4 & $16.86 \mathrm{~b}$ & $16.96 \mathrm{~b}$ & $3.92 \mathrm{~b}$ & $4.00 \mathrm{~b}$ & $17.48 \mathrm{~b}$ & $17.44 \mathrm{~b}$ \\
\hline & 6 & $17.79 \mathrm{a}$ & $17.89 \mathrm{a}$ & $4.16 \mathrm{a}$ & $4.31 \mathrm{a}$ & $17.51 \mathrm{a}$ & $17.62 \mathrm{a}$ \\
\hline \multirow{3}{*}{$\begin{array}{l}\text { Molas (M) } \\
\text { L Fed. }^{-1}\end{array}$} & 0 & $15.97 \mathrm{c}$ & $16.07 \mathrm{c}$ & $3.71 \mathrm{c}$ & $3.79 \mathrm{c}$ & $17.05 \mathrm{c}$ & $17.11 \mathrm{c}$ \\
\hline & 30 & $16.75 \mathrm{~b}$ & $16.85 \mathrm{~b}$ & $3.87 \mathrm{~b}$ & $3.97 \mathrm{~b}$ & $17.43 \mathrm{~b}$ & $17.49 \mathrm{~b}$ \\
\hline & 60 & $17.13 \mathrm{a}$ & $17.25 \mathrm{a}$ & $4.01 \mathrm{a}$ & $4.12 \mathrm{a}$ & $17.61 \mathrm{a}$ & $17.52 \mathrm{a}$ \\
\hline \multirow{4}{*}{ Interactions } & $G \times S L M$ & ** & ** & ** & $\star *$ & $\star *$ & ** \\
\hline & $G \times M$ & ** & ** & *夫 & ** & *夫 & ** \\
\hline & SLM $\times$ M & $\star \star$ & ** & $\star *$ & ** & ** & $\star \star$ \\
\hline & $G \times S L M \times M$ & ** & ** & ** & ** & ** & ** \\
\hline
\end{tabular}

The chemical composition of sugar beet roots as shown in Table (9) show that $\alpha-$ amino $\mathrm{N}, \%), \mathrm{Na}(\%)$ and $\mathrm{K}(\%)$ were high significantly increased with increasing the application rate of gypsum, sugar factory lime and molas up to 10 and $6 \mathrm{Mg} \mathrm{fed}^{-1}$ and $60 \mathrm{~L} \mathrm{fed}^{-1}$, respectively in both growing seasons. Whereas, the highest values of $\alpha-$ amino $N(2.5,2.28$ and $2.28 \%), \mathrm{Na}$ percent $(9.71,8.59,8.45 \%)$ and $\mathrm{K}(80.8,75.17$ and $74.74 \%)$ were recorded with the application of $10 \mathrm{Mg}$ gypsum fed ${ }^{-1}, 6 \mathrm{Mg} \mathrm{SLM}^{-\mathrm{C}^{-}}$or $60 \mathrm{~L}^{\mathrm{molas}} \mathrm{Fed}$ ${ }^{1}$, respectively. The interaction between gypsum, SLM and molas was high significantly on $\alpha$ - amino $\mathrm{N}, \mathrm{Na}$ and $\mathrm{K}$ percentages in root juice.

The sugar loss (\%), sugar recovery (\%) and recoverable sugar yield $\left(\mathrm{Mg} \mathrm{fed}^{-1}\right)$ are shown in Table (10). The highest values of sugar loss $(0.299$, 0.287 and $0.288 \%$ ), , sugar recovery (\%) (18.66, 17.77 and $17.83 \%)$ and recoverable sugar yield $\left(4.01,3.14\right.$ and $\left.3.01 \mathrm{Mg} \mathrm{fed}^{-1}\right)$ were given with the application of $10 \mathrm{Mg}$ gypsum fed ${ }^{-1}, 6 \mathrm{Mg} \mathrm{SLM} \mathrm{fed}^{-1}$ and $60 \mathrm{~L} \mathrm{molas} \mathrm{fed}^{-1}$, respectively. Also, it could be concluded from the data that the combined application from gypsum, SLM and molas can be overcome some problems of the saline-sodic soils and achieve good quality of sugar beet cultivated in these soils. 
Table (9): Effect of gypsum, sugar factory lime mixture and molas application on á- amino $\mathrm{N}, \mathrm{Na}$ and $\mathrm{K}(\%)$

\begin{tabular}{|c|c|c|c|c|c|c|c|}
\hline \multirow[b]{2}{*}{ s } & \multirow[b]{2}{*}{ Rate } & \multicolumn{2}{|c|}{ á- amino N (\%) } & \multicolumn{2}{|c|}{$\mathrm{Na}(\%)$} & \multicolumn{2}{|c|}{ K (\%) } \\
\hline & & $\begin{array}{c}1^{\text {st }} \\
\text { season }\end{array}$ & $\begin{array}{c}2^{\text {nd }} \\
\text { season }\end{array}$ & $\begin{array}{c}1^{\text {st }} \\
\text { season }\end{array}$ & $\begin{array}{c}2^{\text {nd }} \\
\text { season }\end{array}$ & $\begin{array}{c}1^{\text {st }} \\
\text { season }\end{array}$ & $\begin{array}{c}2^{\text {nd }} \\
\text { season }\end{array}$ \\
\hline \multirow{4}{*}{$\begin{array}{l}\text { Gypsum } \\
\text { (G) } \\
\text { Mg Fed. } .^{-1}\end{array}$} & 0 & $1.56 \mathrm{~d}$ & $1.56 \mathrm{~d}$ & $5.15 \mathrm{~d}$ & $5.14 \mathrm{~d}$ & $71.11 \mathrm{~d}$ & $71.11 \mathrm{~d}$ \\
\hline & 5 & $2.13 \mathrm{c}$ & $2.13 \mathrm{c}$ & $8.57 \mathrm{c}$ & $8.57 \mathrm{c}$ & $71.38 \mathrm{c}$ & $71.38 \mathrm{c}$ \\
\hline & 7.5 & $2.48 \mathrm{~b}$ & $2.48 \mathrm{~b}$ & $9.20 \mathrm{~b}$ & $9.20 \mathrm{~b}$ & $73.03 \mathrm{~b}$ & $73.03 \mathrm{~b}$ \\
\hline & 10 & $2.50 \mathrm{a}$ & $2.50 \mathrm{a}$ & $9.71 \mathrm{a}$ & $9.71 \mathrm{a}$ & $80.90 \mathrm{a}$ & $80.90 \mathrm{a}$ \\
\hline \multirow{3}{*}{$\begin{array}{l}\text { SLM } \\
\text { Mg Fed. }^{-1}\end{array}$} & 0 & $2.08 \mathrm{c}$ & $2.08 \mathrm{C}$ & $7.70 \mathrm{c}$ & $7.70 \mathrm{c}$ & $72.77 \mathrm{c}$ & $72.77 \mathrm{C}$ \\
\hline & 4 & $2.15 \mathrm{~b}$ & $2.15 \mathrm{~b}$ & $8.19 \mathrm{~b}$ & $8.18 \mathrm{~b}$ & $74.38 \mathrm{~b}$ & $74.38 \mathrm{~b}$ \\
\hline & 6 & $2.28 \mathrm{a}$ & $2.28 \mathrm{a}$ & $8.59 \mathrm{a}$ & $8.58 \mathrm{a}$ & $75.17 \mathrm{a}$ & $75.17 \mathrm{a}$ \\
\hline \multirow{3}{*}{$\begin{array}{l}\text { Molas (M) } \\
\text { L Fed. }^{-1}\end{array}$} & 0 & $2.08 \mathrm{c}$ & $2.12 \mathrm{~b}$ & $7.94 \mathrm{c}$ & $7.94 \mathrm{c}$ & $72.99 \mathrm{c}$ & $72.99 \mathrm{c}$ \\
\hline & 30 & $2.15 \mathrm{~b}$ & $2.12 \mathrm{~b}$ & $8.08 \mathrm{~b}$ & $8.08 \mathrm{~b}$ & $74.58 \mathrm{~b}$ & $74.58 \mathrm{~b}$ \\
\hline & 60 & $2.28 \mathrm{a}$ & $2.27 \mathrm{a}$ & $8.45 \mathrm{a}$ & $8.45 \mathrm{a}$ & $74.74 \mathrm{a}$ & $74.74 \mathrm{a}$ \\
\hline \multirow{4}{*}{ Interactions } & $\mathrm{G} \times \mathrm{SLM}$ & ** & ** & ** & ** & ** & ** \\
\hline & $G \times M$ & $\star *$ & ** & ** & ** & ** & ** \\
\hline & SLM $\times$ M & ** & ** & ** & ** & ** & ** \\
\hline & $\begin{array}{c}G \times S L M \\
\times M\end{array}$ & ** & ** & ** & ** & ** & ** \\
\hline
\end{tabular}

Table (10): Sugar loss (\%), sugar recovery (\%) and recoverable sugar yield (Mg fed. ${ }^{-1}$ ) as affected by different treatments

\begin{tabular}{|c|c|c|c|c|c|c|c|}
\hline \multirow[b]{2}{*}{ Treatments } & \multirow[b]{2}{*}{ Rate } & \multicolumn{2}{|c|}{ Sugar loss (\%) } & \multicolumn{2}{|c|}{ Sugar recovery (\%) } & \multicolumn{2}{|c|}{ Sugar yield $\left(\mathrm{Mg} \mathrm{fed}^{-1}\right)$} \\
\hline & & $\begin{array}{c}1^{\text {st }} \\
\text { season }\end{array}$ & $\begin{array}{c}2^{\text {nd }} \\
\text { season }\end{array}$ & $1^{\text {st }}$ season & $2^{\text {nd }}$ season & $\begin{array}{c}1^{\text {st }} \\
\text { season }\end{array}$ & $\begin{array}{c}2^{\text {nd }} \\
\text { season }\end{array}$ \\
\hline \multirow{4}{*}{$\begin{array}{l}\text { Gypsum (G) } \\
\text { Mg Fed. }^{-1}\end{array}$} & 0 & $0.280 \mathrm{c}$ & $0.280 \mathrm{c}$ & $16.39 \mathrm{~d}$ & $16.40 \mathrm{~d}$ & $1.77 \mathrm{~d}$ & $1.79 \mathrm{~d}$ \\
\hline & 5 & $0.280 \mathrm{c}$ & $0.280 \mathrm{c}$ & $16.45 \mathrm{c}$ & $16.46 \mathrm{c}$ & $2.53 \mathrm{c}$ & $2.55 \mathrm{c}$ \\
\hline & 7.5 & $0.283 \mathrm{~b}$ & $0.283 \mathrm{~b}$ & $16.83 \mathrm{~b}$ & $16.84 \mathrm{~b}$ & $3.19 \mathrm{~b}$ & $3.20 \mathrm{~b}$ \\
\hline & 10 & $0.299 \mathrm{a}$ & $0.299 \mathrm{a}$ & $18.66 \mathrm{a}$ & $18.67 \mathrm{a}$ & $4.01 \mathrm{a}$ & $4.02 \mathrm{a}$ \\
\hline \multirow{3}{*}{$\begin{array}{l}\text { SLM } \\
\text { Mg Fed. }^{-1}\end{array}$} & 0 & $0.282 \mathrm{~b}$ & $0.282 \mathrm{c}$ & $16.77 \mathrm{c}$ & $16.78 \mathrm{c}$ & $2.57 \mathrm{c}$ & $2.58 \mathrm{c}$ \\
\hline & 4 & $0.286 \mathrm{a}$ & $0.286 \mathrm{a}$ & $17.15 \mathrm{~b}$ & $17.16 \mathrm{~b}$ & $2.93 \mathrm{~b}$ & $2.94 \mathrm{~b}$ \\
\hline & 6 & $0.287 \mathrm{a}$ & $0.287 \mathrm{a}$ & $17.77 \mathrm{a}$ & $17.34 \mathrm{a}$ & $3.13 \mathrm{a}$ & $3.14 \mathrm{a}$ \\
\hline \multirow{3}{*}{$\begin{array}{l}\text { Molas (M) } \\
\text { L Fed. }^{-1}\end{array}$} & 0 & $0.283 \mathrm{c}$ & $0.282 \mathrm{~b}$ & $16.83 \mathrm{c}$ & $16.84 \mathrm{c}$ & $2.71 \mathrm{c}$ & $2.71 \mathrm{c}$ \\
\hline & 30 & $0.286 \mathrm{~b}$ & $0.286 \mathrm{a}$ & $17.19 \mathrm{~b}$ & $17.20 \mathrm{~b}$ & $2.92 \mathrm{~b}$ & $2.94 \mathrm{~b}$ \\
\hline & 60 & $0.288 \mathrm{a}$ & $0.287 \mathrm{a}$ & $17.83 \mathrm{a}$ & $17.24 \mathrm{a}$ & $2.99 \mathrm{a}$ & $3.01 \mathrm{a}$ \\
\hline \multirow{4}{*}{ Interactions } & $\mathrm{G} \times \mathrm{SLM}$ & $\star \star *$ & $\star *$ & $\star \star$ & $\star *$ & $\star \star$ & $* \star$ \\
\hline & $G \times M$ & $\star \star$ & $\star \star$ & $\star \star$ & $\star \star$ & $\star \star$ & ** \\
\hline & $\mathrm{SLM} \times \mathrm{M}$ & ** & ** & ** & ** & ** & ** \\
\hline & $\begin{array}{c}G \times S L M \times \\
M\end{array}$ & ** & $\star *$ & ** & ** & ** & ** \\
\hline
\end{tabular}

\section{Economic evaluation:}

It is well known that any agricultural system should be evaluated from the economic point of view. Therefore, the total outcomes and incomes should be calculated. So, the current soil amendments were evaluated taking in consideration the yield of sugar beet and its quality. The economic evaluation of this study includes calculation of the total net income (LE fed. ${ }^{-1}$ ) , the total costs (LE fed. $\left.{ }^{-1}\right)$, net income from water unit $\left(\mathrm{LE} \mathrm{m}^{-3}\right)$ and economic efficiency. Due to the highest values of root and shoot yields beside the total net income resulting from the application of gypsum, sugar lime mixture and molas, which ameliorated the saline-sodic soils, the economic efficiency for 
the previous amendments were increased with increasing their rate of application. The economic efficiency values were 1.58, 1.18 and 1.07 for gypsum, SLM and molas, respectively at their highest application rates (Table 11). The amendment can be arranged, due to its effect on root of sugar beet, total income, net income, Net efficiency from water unit and economic Eff. in the order of: $G^{*} S L M^{*} M>G^{*} S L M>G^{*} M>G>S L M * M>S L M>M$.

Table (11): The total and net income from water unit and economic efficiency of sugar beet as affected by different treatments

\begin{tabular}{|c|c|c|c|c|c|c|c|c|c|c|}
\hline \multirow[b]{2}{*}{ Treatments } & \multirow[b]{2}{*}{ Rate } & \multirow[b]{2}{*}{$\begin{array}{l}\text { Root } \\
\left(\mathrm{Mg}^{-1}\right)\end{array}$} & \multirow[b]{2}{*}{$\begin{array}{l}\text { Shoot } \\
(\mathrm{Mg} \\
\left.\text { fed }^{-1}\right)\end{array}$} & \multirow{2}{*}{\multicolumn{2}{|c|}{$\begin{array}{c}\text { Total income } \\
\left(\text { LE fed }^{-1}\right)\end{array}$}} & \multirow[b]{2}{*}{$\begin{array}{c}\text { Total } \\
\text { income } \\
\text { (TI) }\end{array}$} & \multirow[b]{2}{*}{$\begin{array}{c}\text { Total } \\
\text { costs } \\
\text { (TC) }\end{array}$} & \multirow[b]{2}{*}{$\begin{array}{c}\text { Net } \\
\text { income } \\
\text { (NI) }\end{array}$} & \multirow[b]{2}{*}{$\begin{array}{l}\text { Net } \\
\text { IWU }\end{array}$} & \multirow[b]{2}{*}{$\begin{array}{l}\text { Eco. } \\
\text { Eff. }\end{array}$} \\
\hline & & & & & & & & & & \\
\hline \multirow{4}{*}{$\begin{array}{l}\text { Gypsum } \\
\left(\mathrm{Mg}^{-1}\right. \\
\left.\mathrm{fed}^{-1}\right)\end{array}$} & 0 & 10.85 & 2.73 & 4341 & 163.8 & 4505 & 3180 & 1325 & 0.46 & 0.42 \\
\hline & 5 & 15.40 & 3.49 & 6172 & 209.9 & 6382 & 3300 & 3082 & 1.07 & .93 \\
\hline & 7.5 & 18.90 & 4.22 & 7663 & 253.8 & 7917 & 3420 & 4497 & 1.55 & 1.31 \\
\hline & 10 & 21.46 & 5.21 & 8820 & 31 & 3 & 3540 & 5593 & 93 & 58 \\
\hline \multirow{3}{*}{$\begin{array}{l}\text { sugar lime } \\
\text { mixture } \\
\left(\text { Mg fed }^{-1}\right)\end{array}$} & 0 & 15.24 & 3.54 & 6131 & 212.9 & 6344 & 3310 & 3034 & 1.05 & 0.90 \\
\hline & 4 & 16.00 & 3.75 & 6484 & 225.5 & 6710 & 3330 & 3380 & 1.17 & .99 \\
\hline & 6 & 17.82 & 4.23 & 7262 & 254.3 & 7516 & 3410 & 4106 & 1.42 & 1.18 \\
\hline \multirow{3}{*}{$\begin{array}{l}\text { Molas } \\
\left(\text { L fed }^{-1}\right)\end{array}$} & 0 & 15.80 & 3.69 & 6321 & 221.8 & 6542 & 3321 & 3221 & 1.11 & 0.95 \\
\hline & 30 & 16.80 & 3.92 & 6815 & 235.4 & 7050 & 3360 & 3690 & 1.28 & 1.08 \\
\hline & 60 & 16.72 & 3.99 & 6843 & 239.6 & 7083 & 3380 & 3703 & 1.28 & 1.07 \\
\hline \multirow{4}{*}{ Interactions } & $\mathrm{G} \times \mathrm{SLM}$ & 22.829 & 5.866 & 9438.6 & 352.0 & 9790.6 & 3590 & 6200.6 & 2.14 & 1.73 \\
\hline & $G \times M$ & 21.856 & 5.413 & 9188.2 & 324.8 & 9513.0 & 3570.0 & 5943.0 & 2.05 & 1.66 \\
\hline & SLM $\times M$ & 18.504 & 4.352 & 7646.1 & 261.2 & 7907.3 & 3440.0 & 4467.2 & 1.54 & 1.28 \\
\hline & $\times$ SLM $\times M$ & 23.065 & 5.981 & 9802.6 & 358.9 & 10161.5 & 3620.0 & 6541.5 & 2.26 & 1.81 \\
\hline
\end{tabular}
Economic efficiency $=$ net income $\left(\right.$ LE fed. $\left.^{-1}\right) /$ total cost (LE fed. $\left.{ }^{-1}\right)$

Net income from water unit $\left(\right.$ LE $\left.\mathrm{m}^{-3}\right)=$ net income $\left(\right.$ LE fed. $\left.{ }^{-1}\right) /$ applied water $\left(\mathrm{m}^{3} \mathrm{fed}^{-1}\right)$

Where: the applied water calculated as $2895 \mathrm{~m}^{3} \mathrm{fed}^{-1}$ in one season

Net IWU = Net income from water unit $\left(\right.$ LE $\left.\mathrm{m}^{-3}\right)$

Eco. Eff. = Economic efficiency. TC, total costs whereas $\mathrm{Tl}$, total income and NI, net income in LE fed. ${ }^{-1}$

\section{CONCLUSIONS}

Because of the importance of salt-affected soils, the advances in this field will be continued searching about the new approaches to overcome their problems. In Egypt, these soils represent a significant area and its investment is crucial. This study presented some soil amendments including the old one (gypsum) and the new one (molas and sugar factory lime) even separated or in combined application. One of the major shortcomings in gypsum application at uniform rates, which lower its efficiency because of the special variability under the salt-affected soil conditions. The efficiency of gypsum can be increased if it applied at variable rates according to its requirements to the soil but again it needs extra analysis that may not be economic in some cases. Also ,huge amounts of sugar factory lime wastes can be used as a source of some organic acids and calcium to increase the exchangeable $\mathrm{Ca}$ in soil solution and remove $\mathrm{Na}$ from soil surface. Concerning molas, it 
contains some organic acids, vitamins and non-nitrogenous organic acids to help the cultivated plants in overcoming the salinity stress.

From this study, it could be concluded that, the combined application of gypsum, sugar lime mixture and molas at the rate of $10,6 \mathrm{Mg} \mathrm{fed}^{-1}$ and 60 $\mathrm{L}$ fed. ${ }^{-1}$, respectively could be used to improve the salt-affected soils in North Delta. Further studies should be carried out concerning these amendments using different plant species and different kinds of salt-affected soils. The biological activities in soil should be taken in consideration under such saltaffected soils and its roles in enhancing cultivated plants to overcome the problems of these soils.

\section{REFERENCES}

Abd El-Hamid, Azza ,R. ; Mansour, S. F. ; EL-Maghraby, T. A. and Barky, M. A. A. (2011). Competency of some soil amendments used for improvement of extreme salinity of Sahl El-Tina soil .J. Soil Sci. and Agric. Eng. Mansoura Univ., 2 (6): 649-667.

Abdel-Fattah, M. K. (2012). Role of gypsum and compost in reclaiming saline-sodic soils. J. of Agric. and Veterinary Sci., 1 (3): 30-38.

Abdurrahman H.; Fatih, B.; Fatih, M. and Mustafa, Y. (2004) Reclamation of Saline-Sodic Soils with Gypsum and MSW Compost. J. Compost Science \& Utilization, 12(2:175-179.

Ag Gold Standard (2008). The value and benefits of lime. http://www.crystalsugar.com/agronomy/gold/fact/lime.pdf (16 Nov. 2012).

Ali, L.K.M. (1993). An evaluation of adding different sources of gypsum for improving soil productivity under field conditions. M.Sc. Thesis, Fac. of Agric. Ain Shams Univ.A.R.E..

Amer, M.M. and El-Ramady, H. R. (2015). Alleviation Soil Salinity and Sodicity Hazard using some bio-chemical Amendments for Production of canola (Brassica napus L.) in North Delta Region J. Soil Sci. and Agric. Eng. Mansoura Univ. (in press).

Amezketa, E. A. ; Aragues, R. and Gazol, R. (2005). Efficiency of sulfuric acid, mined gypsum and two gypsum by-products in soil crusting prevention and sodic soil reclamation. Agron. J., 97: 983-989.

AOAC (1995). Association of Official Analytical Chemists. $16^{\text {th }}$ Eds., Official Methods of Analysis, Washington, DC.

Avinmelech Y.; Kochva, M.; Yotal, Y. and Shked, D. (1992) The use of compost as a soil amendment . International symposium on compost recycling of wastes. 1, (38) Athens, Greece.

Blake, G.R. and Hartge, K.H.(1986). Bulk Density," In: A. Klute, et al., Eds., Methods of Soil Analysis, Part I, ASA.

Cha-um, S. and Kirdmanee, C. (2011). Remediation of salt-affected soil by the addition of organic matter: an investigation into improving glutinous rice productivity. Sci. Agric. (Piracicaba, Braz.), 68 (4): 406410. 
Cooke, D. A. and Scott, R. K. (1993). The Sugar Beet Crop. Chapman and Hall, Publisher London, pp: 675.

Dickson, P.H.; A. Groenevelt and Rasiah, V. ( 1990) Evaluation of two selected industrial wastes for disposal on cropland. Soil Technology 3(2): 167-172

Early, A. C. (1975). Irrigation Scheduling for wheat in the Punjab. CENTO Scientific programme on the optimum use of water in Agric. Report No. 17, Lyallpur, Pakistan, March,3-5,pp.115-127.

El Morsy, E.A. (2014).Soil improvement and reclamation. Fac. of Agric. Cairo Univ.A.R.E. book in Arabic, cod222, term 4 lecture 6, pp32-33.

El-Samanoudi, I.M.; Mohamed S.A. and Danial, H.F. (1991).Relationships between soil aggregation, pore size distribution and hydraulic conductivity in sandy clay loam soils. $2^{\text {nd }}$ African Soil Sci. Conf. pp.209-217.

FAO (2005). Integrated management for sustainable use of salt-affected soils. (Eds. A. Mashali, D.L. Suarez, H. Nabhan, R. Rabindra). FAO Soils Bulletin, Rome.

Garcia, G. (1978). Soil water Engineering Laboratory Manual. Colorado State Univ. Dept. of Agric. and Chemical Engineering. Fort Collins, Colorado.

Gomez, K. A. and Gomez, A. A. (1984). Statistical procedures for agricultural research. $2^{\text {nd }}$ ed. John Wiley and Sons, New York, 680.

Habib, F. M.; Abd El-Hameed A.H.; Awaad M.S. and Deshesh T.H.M.A. (2009). Effect of some organic conditioners on some chemical and physical properties of newly reclaimed soils in Egypt. J. Soil Sci. and Agric. Eng. Mansoura Univ., 34 (12): 11537-11547.

Hanay, A., Buyuksonmez, F. , Kizilolu, F. M. and Canbolat, M. Y.(2004). Reclamation of saline sodic soils with gypsum and MSW compost. Compost Sci. and Utilization, 12(2): 175-179.

Howell, T. A.; Cuence, R. H. and Solomon, K. H. (1990). Crop yield response. In: Management of farm irrigation systems. Hoffman, G. J., T. A. Howell and K. H. Solomon (Eds.). ASAE, St. Joseph, MI., USA, pp: 312.

Ilyas, M.; Qureshi, R. H. and Qadir, M. A. (1997) Chemical changes in a saline-sodic soil after gypsum application and cropping. J. Soil Technol., 10(3): 247-260.

Ippolito, J. A., Strawn, D. G. and Scheckel, K. G. (2013). Investigation of copper sorption by sugar beet processing lime waste. J. Environ. Qual. 42: 919-924.

Mansour, S.F; Mohamedin, A.A.M. and Mahmoud, M.M. (2011). Evaluation of some soil amendments and their applied methods on the reclamation of saline-sodic soils. J. of Biological Chemistry Environmental Sci.,6 (4):167-181.

Mohamed, H. F. (2002). Chemical and technological studies on sugar beet. Ph.D. Thesis, Faculty of Agric, Minia Univ., Egypt. 
Mohamedin, A.A.M.; Ismail, A.O.A. and Seyam, H. M.M. (2012). Use Efficiency of Soil Amendments and Saline Water on Improving Properties and Productivity of Sodic Soil Egypt. J. of Appl. Sci., 27( 1): $51-60$

Oster, J.D. and Frenkel, H. (1980). The chemistry of the reclamation of sodic soils with gypsum and lime. Soil Sci. Soc. Am. J., 44:41-45.

Page, A. L. R., Miller, H. and Keeney, D. R. (1982). Methods of Soil Analysis. Part 2: Chemical and Microbiological Properties. $2^{\text {nd }}$ Edition, Agronomy Monograph, No. 9, ASA, CSSA, and SSSA, Madison.

Qadir, M., S., Schubert, A. D. Noble, M. Saqib and Saifulla,H (2006). Amelioration strategies for salinity-induced land degradation. $C A B$ Reviews: Perspectives in Agric., Veterinary Sci., Nutrition and Natural Resources 1, No. 069.

Richards, L. A. (1954). Diagnosis and improvement of saline and alkali soils. Soil Sci.,(78), $2: 154$.

Sharma, R.D.;Ali, S.and Plant, G.B. (1996).Effect of soil amendments on rice yield. IRRI Notes, 21:72-3.

Tejada, M., Garcia, C., Gonzalez, J. L. and Hernandez, M. T. (2006). Use of organic amendment as a strategy for saline soil remediation: Influence on the physical, chemical and biological properties of soil. Soil Biology and Biochemistry 38: 1413-1421.

Van Beers, W.F.J. (1958).The Auger-Hole method, Bulletin 1, Int. Inst. for land recl. and impor, Wageningen, The Netherland.

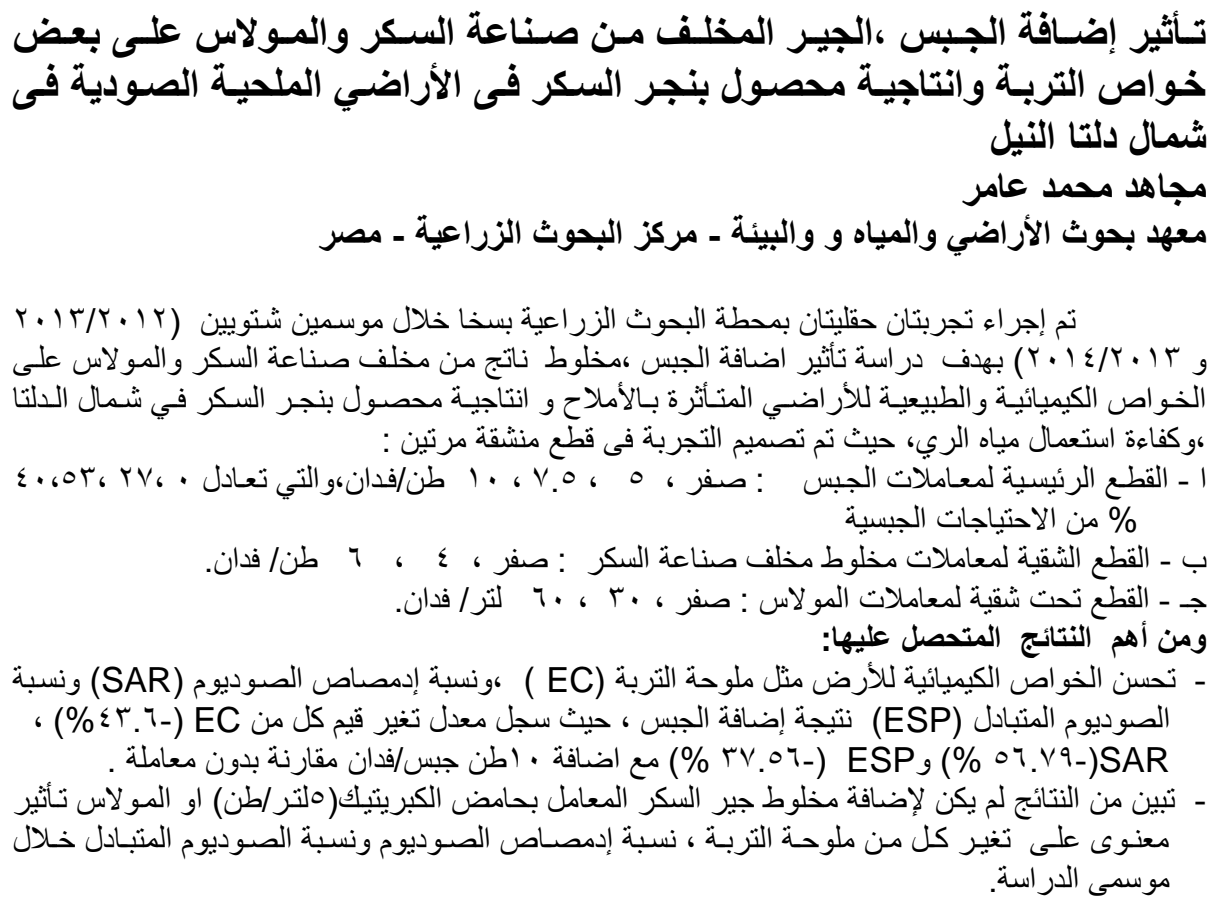


ــ توضح النتائج تحسن معنوى فى بعض الخواص الكيميائية للتربة (EC,SAR,ESP) نتيجة التفاعل بين المعاملات مقارنة بالمعاملة الفردية او بدون معاملة الفيلة.

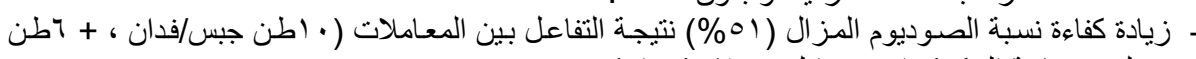

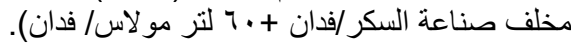

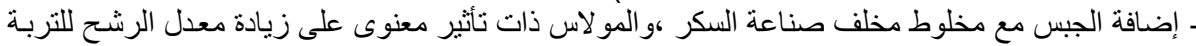

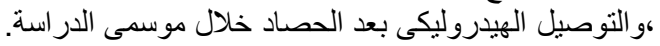

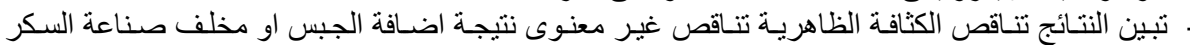

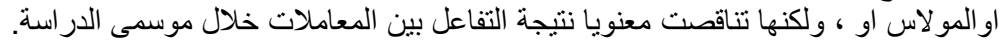

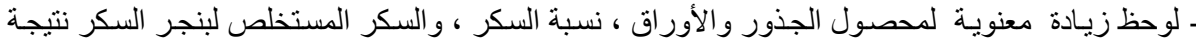

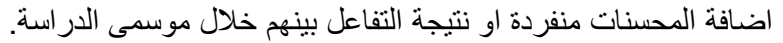

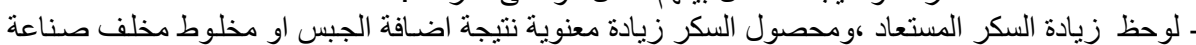

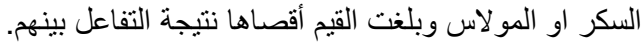

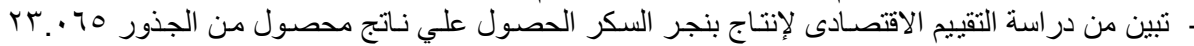

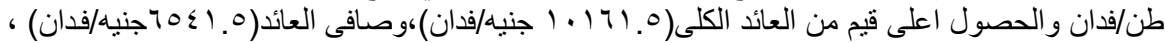

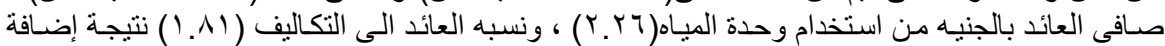

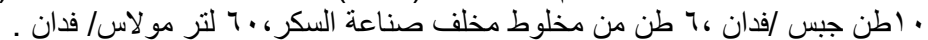

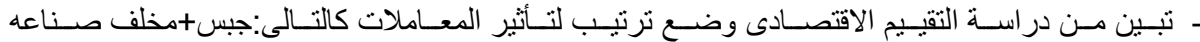

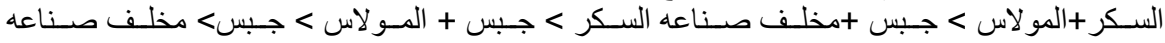

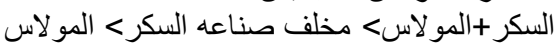

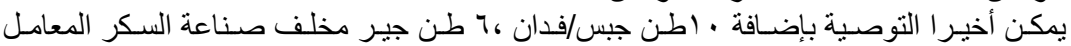

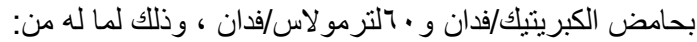

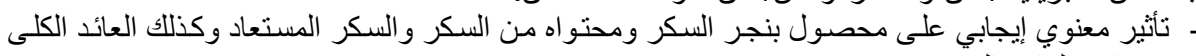

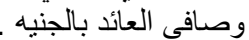
ـ تحسين بعض من الخواص الطبيعية و الكيميائية للتربة وبالنالي تعظيم إنتاجية الأراضي المتأثرة بالأملاح في 